Mohamad Muspawi /_Ta'dib: Jurnal Pendidikan Islam, Vol. 9 No. 1 (2020) 20-30

ISSN 1411-8173 | E-ISSN 2528-5092

https://ejournal.unisba.ac.id/index.php/tadib/article/view/5932

\title{
THE ROLE OF LEADERS IN INCREASING MOTIVATION TEACHER WORK IN PONDOK PESANTREN
}

\author{
Mohamad Muspawi \\ Universitas Jambi \\ Email: muspawi01@gmail.com \\ DOI: https://doi.org/10.29313/tjpi.v9i1.5932 \\ Submitted: April 16th, 2020. Approved: May 26th, 2020. Published: May 26th, 2020
}

\begin{abstract}
This study aims to determine the role of leaders in Islamic boarding schools As'ad Jambi City in increasing teacher work. motivation. The research target is to find out: 1). The role of leaders in increasing teacher work motivation, 2). Leadership constraints in increasing teacher work motivation, and how to overcome them. The method used is a qualitative method, which describes the research findings in a narrative and straightforward manner. Data collection was carried out by observation, documentation, and interview techniques. Checking the validity of the data is done by observing persistence, triangulation, member checks, and audit trail. Data analysis was carried out by analyzing and reducing data, unitizing data, categorizing data, and interpreting data. The results showed that; First, the role of leaders in increasing teacher work motivation includes giving rewards and punishments, inviting teachers to work sincerely, improving work facilities, and maintaining closeness to teachers. Second, the constraints of the leadership in increasing teacher work motivation include; 1) lack of funds, is overcome by providing an understanding to teachers so that they are equally understanding of financial limitations, and strive to meet basic needs that are affordable with existing finances. 2) The diversity of the wishes of the teachers, is overcome by meeting only affordable needs, in the hope that the teachers can accept the existing situation.
\end{abstract}

Keywords: Leader; Teacher Work Motivation; Islamic boarding school.

\begin{abstract}
Abstrak
Penelitian ini bertujuan untuk mengetahui peran pemimpin dipondok pesantren As'ad Kota Jambi dalam meningkatkan motivasi kerja guru. Target penelitian adalah untuk mengetahui: 1). Peran pemimpin dalam meningkatkan motivasi kerja guru, 2). Kendala pimpinan dalam meningkatkean motivasi kerja guru, dan bagaimana cara mengatasinya. Metode yang digunakan adalah metode kualitatif, yakni menguraikan temuan penelitian secara naratif dan apa adanya. Pengumpulan data yang dilakukan dengan teknik obervasi, dokumentasi, dan wawancara. Mengecek validitas data dilakukean dengan ketekunan pengamatan, triangulasi, member check, dan audit trail. Alisis data dilakukan dengan penelaahan dan reduksi data, unitisasi data, kategorisasi data, dan interpretasi data. Hasil penelitian menunjukean bahwa; pertama, peran pimpinan dalam meningkatkan motivasi kerja guru adalah meliputi pemberikan reward dan punishment, ajakan kepada guru untuk bekerja secara ik.hlas, peningkatan fasilitas kerja, serta menjaga kedekatan dengan para guru. Kedua, kendala pimpinan dalam meningkatkan motivasi kerja guru meliputi; 1) kekurangan dana, diatasi dengan memberikan pemahaman kepada para guru agar sama-sama memaklumi akan keterbatasan keuangan, dan berupaya memenubi kebutuhan-kebutuhan pokok yang terjangkau dengan keuangan yang ada. 2) Keberagaman keinginan para guru, diatasi dengan memenubi kebutuban yang terjangkau saja, dengan harapan para guru bisa menerima keadaan yang ada.
\end{abstract}

Kata Kunci: Pemimpin; Motivasi Kerja Guru; Pondok Pesantren. 


\section{PENDAHULUAN}

Kesuksesan seorang guru dalam mengajar dapat dipengaruhi oleh tingginya motivasi yang dimiliki oleh guru tersebut. Dengan motivasi yang baik maka guru biasanya menunjukkan kinerja yang maksimal, semangat dalam mengajar, tekun dalam menghadapi berbagai halangan dan rintangan atas pekerjaannya sebagai seorang guru.

Siagian (2009) mengatakan bahwa motivasi merupakan daya dorong bagi seseorang untuk memberikan kontribusi yang sebesar mungkin demi keberhasilan organisasi mencapai tujuannya. Dengan pengertian, bahwa tercapainya tujuan organisasi berarti tercapai pula tujuan pribadi para anggota yang bersangkutan. Selanjutnya, Achua dan Luissier (2010) mengemukakan definisi motivasi dengan segala sesuatu yang dapat mempengaruhi perilaku dalam mencapai tujuan tertentu. Manullang (2007) menjelaskan bahwa menurut arti katanya, motivasi berarti pemberian motif, penimbulan motive atau hal yang menimbulkan dorongan atau keadaan yang menimbulkan dorongan. Motivasi dapat pula diartikan faktor yang mendorong orang untuk bertindak dengan cara tertentu. Dengan kata lain dapat penulis sampaikan bahwa motivasi adalah daya gerak secara instrinsik maupun ekstrinsik yang mendorong seseorang untuk melakukan suatu perbuatan guna mencapai suatu tujuan.

Berkenaan dengan bagaimana teknik memotivasi, Usman (2009) mengemukakan enam cara yang dapat dilakukan yaitu berpikir positif, menciptakan perubahan yang kuat, membangun harga diri, memantapkan pelaksanaan, membangkitkan orang lemah menjadi kuat, dan membasmi sikap suka menunda-nunda.

Secara teoritis, memang ada hal penting yang membangkitkan motivasi seseorang, sebagaimana yang dikatakan oleh Ivancevich (2013) bahwa gagasan staf/ karyawan memuaskan kebutuhan sebagai cara untuk merancang pekerjaan berasal dari teori dua faktor Herzberg motivasi kerja. Ide dasarnya adalah bahwa karyawan akan termotivasi oleh pekerjaan yang meningkatkan perasaan harga diri mereka.

Pemimpin sebuah lembaga tentu selalu melakukan berbagai cara untuk meningkatkan motivasi para staf mereka dalam bekerja. Pemimpin sekolah atau lebih dikenal dengan istilah kepala sekolah adalah seorang guru yang diangkat secara sah untuk memduduki jabatan struktural di sekolah yang ditugaskan untuk mengelola sekolah (Wahjosumidjo, 2010). Atau dengan kata lain dapat penulis sampaikan bahwa kepala sekolah adalah seorang guru dengan memenuhi serangkaian syarat yang diangkat dan ditugaskan secara legal untuk memimpin sebuah sekolah.

Hasil penelitian yang dilakukan oleh Setyati (2014) menunjukkan bahwa; (1) ada pengaruh yang positif dan signifikan antara kepemimpinan kepala sekolah, motivasi kerja, budaya sekolah terhadap kinerja guru dimana kontribusi yang diberikan sebesar 42,2\%, (2) ada pengaruh yang positif dan signifikan antara kepemimpinan kepala sekolah terhadap kinerja guru dengan sumbangan efektifnya sebesar $18,22 \%$, (3) ada pengaruh yang positif dan signifikan antara motivasi kerja terhadap kinerja guru dengan sumbangan efektifnya sebesar $13,03 \%$, dan (4) ada pengaruh yang positif dan signifikan antara budaya sekolah efektifitas terhadap kinerja guru dengan sumbangan efektifnya sebesar 10,94\%.

Kemudian, Istilah pemimpin pada Pondok Pesantren As'ad kota Jambi dalam penelitian ini disebut Mudir. Selaku pemimpin tertinggi dalam struktural pesantren, mudir merupakan pihak yang ikut berjasa dan bertanggung jawab untuk membantu para guru memiliki motivasi yang tinggi. Kepemimpinan mudir yang baik akan memberikan dampak yang baik pula bagi para guru dalam menjalankan aktivitasnya dengan motivasi kerja yang baik, sebaliknya kepemimpinan mudir yang buruk bisa pula memberikan efek yang kurang baik bagi motivasi guru. (Mulyasa, 2004:107) mengatakan bahwa kepemimpinan berfungsi sebagai kekuasaan dasar pemimpin untuk mengajak, mempengaruhi, dan menggerakkan orang lain 
untuk melaksanakan sesuatu guna mencapai suatu tujuan yang telah ditetapkan.

Mudir selaku pemegang puncak pimpinan bagi sebuah pondok pesantren, tentu menginginkan bahwa para guru yang mengajar pada pondok pesantren yang dipimpinnya memiliki motivasi yang baik. Untuk itu, sebagai wujud tanggung jawabnya, mudir akan selalu membina para guru agar stabilitas motivasi tetap terjaga, mudir tentu juga akan mengupayakan berbagai hal positif untuk mendorong para guru supaya bekerja dengan motivasi yang baik.

Fakta lapangan pada penelitian terdahulu menunjukkan bahwa tergambar kondisi motivasi para guru yang mengajar di pondok pesantren As'ad cukup baik. Hal itu nampak dari semangat kerja yang ditunjukkan oleh para guru tersebut, mereka terlihat tekun dalam menjalankan berbagai aktivitas mengajarnya, mereka juga terlihat sabar dengan berbagai keterbatasan yang dihadapinya. Motivasi tinggi yang ditunjukkan oleh para guru tersebut merupakan bagian dari cerminan kepemimpinan pondok pesantren tersebut. Hal ini dapat dipahami dengan baiknya kepemimpinan yang dilakukan oleh mudir pondok pesantren As'ad, sehingga dengan kepimpinan yang baik membuat para guru pondok pesantren As'ad selalu memiliki motivasi yang baik pula dalam mengajar.

Kepemimpinan mudir dalam meningkatkan motivasi guru memiliki hubungan dengan hal itu telah dibuktikan oleh beberapa hasil penelitian, antara lain penelitian oleh Thoonen (2011) bertujuan untuk menguji dampak relatif praktik kepemimpinan transformasional, kondisi organisasi sekolah, faktor motivasi guru, dan pembelajaran guru pada praktik mengajar. Rancangan penelitian berupa data dikumpulkan dari survei terhadap 502 guru dari 32 sekolah dasar di Belanda. Sebuah model struktural diuji pada matriks kovarian dalam-sekolah dan uji chi-square dengan memperhitungkan ketidaktergantungan pengamatan. Hasil penelitian menunjukkan bahwa keterlibatan guru dalam kegiatan pembelajaran profesional, khususnya percobaan dan refleksi, merupakan prediktor yang kuat untuk praktik mengajar. Rasa efikasi diri guru nampaknya menjadi faktor motivasi yang paling penting untuk menjelaskan pembelajaran guru dan praktik mengajar. Faktor-faktor motivasi juga memediasi pengaruh kondisi organisasi sekolah dan praktik kepemimpinan pada pembelajaran guru dan praktik mengajar. Akhirnya, praktik kepemimpinan transformasional merangsang pembelajaran dan motivasi profesional guru dan meningkatkan kondisi organisasi sekolah dengan harapan bahwa membangun kapasitas sekolah untuk pembelajaran guru akan meningkatkan praktik mengajar, ada sedikit bukti sistematis untuk mendukung klaim ini. Penelitian ini bertujuan untuk menguji dampak relatif praktik kepemimpinan transformasional, kondisi organisasi sekolah, faktor motivasi guru, dan pembelajaran guru pada praktik mengajar. Kesimpulan dari penelitian ini yaitu untuk pemimpin sekolah mendorong pembelajaran guru dan meningkatkan praktik mengajar diperlukan kombinasi perilaku kepemimpinan transformasional. Penelitian lebih lanjut diperlukan untuk menguji efek relatif dari dimensi kepemimpinan transformasional pada kondisi organisasi sekolah, motivasi guru, dan pembelajaran profesional di sekolah. Akhirnya, kondisi untuk perbaikan sekolah diperiksa pada satu titik waktu. Diperlukan studi longitudinal untuk peningkatan sekolah untuk memodelkan perubahan dalam kapasitas dan pertumbuhan sekolah dan dampak selanjutnya pada praktik mengajar.

Hasil penelitian Usman (2016) menegaskan bahwa gaya kepemimpinan dalam meningkatkan motivasi kerja adalah gaya kepemimpinan konsultatif, partisipatif dan instruktif. Selain itu, terdapat faktor-faktor yang mempengaruhi motivasi kinerja personel yaitu otoritas dan karismatik kepala sekolah di hadapan personel, dan demokratis dalam pengambilan keputusan, dan lingkungan keagamaan. Di sisi lain, faktor-faktor yang membatasi dalam meningkatkan kinerja personel meliputi jumlah siswa yang melebihi asrama kapasitas yang tersedia, beberapa personel tidak memiliki latar 


\section{Mohamad Muspawi /_Ta'dib: Jurnal Pendidikan Islam, Vol. 9 No. 1 (2020) 20-30 \\ ISSN 1411-8173 | E-ISSN 2528-5092 \\ https:// ejournal.unisba.ac.id/index.php/tadib/article/view/5932}

belakang keterampilan administrasi, minoritas personel yang kurang aktif, dan tidak dapat memberikan dukungan keuangan untuk personel.

Hal senada terdapat pada penelitian Suhendar, dkk (2017). Hasil penelitian menunjukan bahwa; terdapat pengaruh langsung kualitas kepemimpinan terhadap budaya pesantren, terdapat pengaruh langsung kualitas kepemimpinan kyai terhadap motivasi kerja guru, terdapat pengaruh langsung kualitas kepemimpinan kyai terhadap mutu pendidikan pesantren, terdapat pengaruh tidak langsung kualitas kepemimpinan kyai terhadap mutu pendidikan pesantren melalui budaya pesantren dan motivasi kerja guru, terdapat pengaruh tidak langsung kualitas kepemimpinan terhadap motivasi kerja guru melalui budaya pesantren, terdapat pengaruh langsung budaya pesantren terhadap motivasi kerja guru, terdapat pengaruh langsung budaya pesantren terhadap mutu pendidikan pesantren, terdapat pengaruh tidak langsung budaya pesantren terhadap mutu pendidikan melalui motivasi kerja guru, dan terdapat pengaruh langsung motivasi kerja guru terhadap mutu pendidikan pesantren.

Mencermati latar belakang permasalahan yang telah dikemukakan, yang menjadi fokus dalam penelitian ini yaitu mengenai kepemimpinan mudir pondok pesantren As'ad, khususnya mengenai peran pemimpin dalam meningkatkan motivasi kerja guru di Pondok Pesantren As'ad.

\section{METODE PENELITIAN}

Penelitian ini menggunakan pendekatan kualitatif yang bertujuan untuk mengkaji permasalahan dan memperoleh makna yang lebih mendalam sesuai dengan latar penelitian. Pertimbangan penggunaan pendekatan kualitatif ialah untuk mempermudah penyesuaian jika berhadapan dengan kenyataan ganda, hakikat relasi peneliti dengan responden dapat disajikan langsung, serta lebih peka dan lebih dapat melakukan penyesuaian diri dengan banyak penajaman pengaruh bersama dan terhadap polapola nilai yang dihadapi.

Penelitian ini merupakan studi kasus di pondok pesantren As'ad Kota Jambi yang merupakan salah satu pondok pesantren yang ada di provinsi Jambi, lebih tepatnya berada di wilayah kelurahan Olak Kemang kecamatan Danau Teluk kota Jambi. Penelitian dimulai dengan observasi awal lokasi penelitian yang dimaksudkan untuk mengenali secara pasti mengenai tempat dilaksanakannya penelitian.

Khusus mengenai sumber data yang berupa subjek atau sampel manusia, pemilihannya dilakukan secara purposive sebagaimana dijelaskan oleh Lincoln dan Guba sebgaimana dikutif oleh Moleong (2010), bahwa peneliti mulai dengan asumsi bahwa konteksnya sendiri, dan peneliti sangat erat kaitannya dengan faktor-faktor kontekstual.

Berdasarkan prosedur sampling, maka yang menjadi subjek penelitian ini adalah $M u d i r$ pondok pesantren, yang merupakan informan kunci bagi penelitian penulis. Sedangkan sebagai informan tambahan, sepuluh orang guru dilibatkan sebagai partisipan.

Penelitian ini dilaksanakan melalui beberapa tahapan, yakni mulai dari tahap persiapan, yang terdiri atas survei literatur, survei lokasi penelitian, pengidentifikasian data awal, dan pengajuan proposal. Tahap pelaksanaan, yang terdiri atas pengumpulan data, pengolahan data, analisis data, dan penyusunan laporan awal. Tahap penyusunan laporan penelitian, yang terdiri atas persiapan seminar dan pelaksanaan seminar, penyusunan laporan akhir, dan penyerahan laporan akhir.

Pengumpulan data dalam penelitian ini menggunakan tiga teknik utama, yaitu observasi, wawancara, dan studi dokumentasi. 1) Observasi. Observasi lakukan secara berkelanjutan agar diperoleh informasi dari tangan pertama mengenai masalah yang diteliti dan kondisi pondok pesantren As'ad kota Jambi. Untuk itu, penulis telah melakukan pengamatan partisipasi aktif dan pasif secara bergantian dengan memperhatikan sifat situasi dan peristiwa yang diamati serta keterlibatan penulis dengan 


\section{Mohamad Muspawi /_Ta'dib: Jurnal Pendidikan Islam, Vol. 9 No. 1 (2020) 20-30 ISSN 1411-8173 | E-ISSN 2528-5092 \\ https:// ejournal.unisba.ac.id/index.php/tadib/article/view/5932}

responden. 2). Wawancara. Pelaksanaan wawancara pada prinsipnya dimaksudkan untuk mendapatkan data yang cukup sehubungan dengan pokok masalah penelitian yang telah diidentifikasi. Kegiatan wawancara ini penulis lakukan secara terus menerus dengan responden dalam berbagai situasi, meskipun kadangkala dilakukan pula dalam situasi yang khusus. Wawancara dalam penelitian ini lebih fokus menggali informasi mengenai berbagai upaya yang dilakukan oleh pimpinan dalam meningkatkan motivasi kerja guru. 3). Dokumen. Teknik lain yang digunakan untuk pengumpulan data ialah mempelajari dokumen. Memahami serangkaian dokumen dimanfaatkan untuk bahan triangulasi dalam mengecek kesesuaian data.

Pengumpulan data ditempuh melalui serangkaian tahap, yaitu tahap orientasi dan overview, yaitu untuk mencari dan mengumpulkan informasi yang diperlukan untuk menetapkan fokus penelitian. tahap eksplorasi (focused exploration), yaitu untuk mempertajam fokus penelitian agar pengumpulan data lebih terarah dan spesifik. dan tahap member check digunakan untuk mengecek kebenaran data atau informasi yang dikumpulkan, tahap ini merupakan tahap untuk memperoleh kredibilitas hasil penelitian.

Pengecekan kesahihan atau keterpercayaan data penelitian ini, dilaksanakan dengan kriteria: (1) kredibilitas/ derajat kepercayaan, transferabilitas/ keteralihan, dependabilitas/ ketergantungan, konfirmabilitas/ kepastian. Sementara untuk pemeriksaan kesahihan data ditempuh dengan cara ketekunan pengamatan, triangulasi data, member check, dan audit trail.

Menganalisis data dilasanakan dengan mengikuti proses yang dianjurkan oleh Moleong (2010), yaitu diawali dengan penelaahan seluruh data yang tersedia dari berbagai sumber, yakni hasil wawancara dan pengamatan yang sudah dituliskan dalam catatan lapangan, dokumen pribadi, dokumen resmi, gambar, foto, dan sebagainya. sedangkan prosedur menganalisis data terdiri atas empat langkah: 1). Reduksi data. yakni memilih data yang sudah disusun dalam laporan, kemudian disusun kembali dalam bentuk uraian terperinci. 2). Unitisasi Data. yakni pembuatan batasan untuk setiap satuan data, kemudian mengkodenya sehingga data yang sudah diperoleh ditransformasikan dan diorganisasi ke dalam unit-unit berdasarkan karakteristiknya. 3). Kategorisasi Data. yakni pemilahan sejumlah unit menjadi satu kategori tertentu berdasarkan kesamaan karakteristiknya. 4). Interpretasi Data. yaitu memaknai data yang telah dikategorisasi dan menggambarkan makna analitik atas unit dan kategori serta keterkaitannya antara satu dengan lainnya.

\section{HASIL PENELITIAN DAN PEMBAHASAN}

\section{HASIL PENELITIAN}

Fokus dalam penelitian ini yaitu mengenai kepemimpinan mudir dalam meningkatkan motivasi guru pada pondok pesantren As'ad kota Jambi. Berdasarkan hasil obervasi dan wawancara yang penulis lakukan kepada subjek penelitian, dapat dikemukakan bahwa kepemimpinan mudir dalam meningkatkan motivasi guru pada pondok pesantren As'ad kota Jambi adalah sebagai berikut.

\section{a. Memberikan reward dan punishment}

Berdasarkan informasi yang disampaikan oleh mudir pondok pesantren As'ad kepada penulis, dapat dikemukakan bahwa salah cara mudir meningkatkan motivasi bagi para guru yang mengajar pada pondok pesantren tesebut adalah dengan memberikan reward dan punishment atau lebih disebut dengan penghargaan dan sanksi. Hal itu dapat dipahami dari hasil wawancara peneliti dengan mudir tersebut sebagai berikut:

"Diantara cara yang saya lakukan dalam rangka meningkatkan motivasi kerja para guru yang mengajar pada pondok pesantren ini adalah dengan memberikan reward dan punishment atau penghargaan dan sanksi. Penghargaan bisa dalam bentuk ucapan terima kasih, pujian, dan terkadang dibelikan baju seragam secara kolektif. Sementara kepada yang kebetulan kurang disiplin maka disampaikan teguran agar berkenan 
memperbaiki diri. Harapan saya dengan cara ini para guru menjadi lebih lebih termotivasi lagi dalam menjalankan tugasnya sebagai guru pada pondok pesantren ini”.

Apa yang disampaikan oleh mudir di atas sesuai pula dengan apa yang disampaikan oleh Partisipan 1 yang merupakan salah seorang guru pada pondok pesantren As'ad, yang mana menurutnya bahwa diantara cara mudir memotivasi para guru ialah dengan memberikan penghargaan dan sanksi kepada para guru. Hal itu dapat diperhatikan dalam hasil wawancara berikut:

"Sejauh yang saya ketahui, bahwa salah satu cara mudir memotivasi para guru yang ada di sini ialah dengan memberikan penghargaan kepada guru berprestasi atau yang menunjukkan kerja bagus, serta memberikan sanksi kepada guru yang dianggap lalai. Penghargaan itu terkadang dalam bentuk pembelian baju seragam kepada para guru, baju seragam tersebut tidak disebutkan khusus untuk mereka yang berprestasi, melainkan semua guru mendapatkannya, tetapi dalam penyerahannya pihak yayasan selalu mengingatkan bahwa pemberian baju seragam diharapkan dapat memotivasi para guru dalam mengajar".

Ketika penulis melakukan observasi ke lapangan, penulis menemukan bahwa terdapat surat teguran yang ditujukan kepada salah seorang guru, surat tersebut disimpan dan diarsipkan dengan rapi oleh bagian tata usaha. Surat tersebut berisi teguran mengenai disiplin kerja, dan tertulis juga harapan agar guru yang bersangkutan memperbaiki diri di masa-masa mendatang. Menurut informasi yang disampaikan oleh bagian tata usaha pondok pesantren As'ad, bahwa surat semacam itu sangat jarang sekali dikeluarkan, hal itu dikarenakan mudir sangat mengedepankan toleransi dan lebih memilih menyampaikan secara lisan.

b. Mengajak guru untuk bekerja secara ikhlas.

Berdasarkan penuturan mudir pondok pesantren As'ad, bahwa cara lain yang dilakukannya dalam rangka meningkatkan motivasi para guru pondok pesantren tersebut dalam bekerja adalah dengan mengajak atau menghimbau mereka untuk bekerja secara ikhlas. Hal dapat diperhatikan dalam hasil wawancara berikut ini.

"Cara lain yang saya lalukan dalam rangka meningkatkan motivasi guru dalam bekerja di pondok pesantren As'ad ini ialah dengan dengan mengajak atau menghimbau mereka untuk bekerja secara ikhlas. Hal itu biasanya saya sampaikan di dalam kegiatan rapat, pertemuanpertemuan, dan pada kegiatan upacara bendera. Bekerja ikhlas yang maksud ini adalah para guru meniatkan apa yang diajarkannya semata-mata karena Allah, dan meyakini bahwa Allah maha mengetahui dengan apa yang mereka kerjakan, sehingga mudah-mudahan Allah membalas dengan balasan yang terbaik dari pekerjaan yang mereka dengan ikhlas."

Ketika penulis melakukan observasi lapangan, penulis memang melihat bahwa dalam kegiatan upacara bendera senin yang kebetulan waktu itu penulis ikut menyaksikannya, terlihat dan terdengar mudir pondok pesantren As'ad dalam penyampaian amanatnya diantara pesannya adalah mengajak para guru untuk selalu bekerja secara ikhlas.

Hasil wawancara penulis dengan mudir pondok pesantren As'ad dan hasil observasi yang telah peneliti lakukan di atas, sejalan pula dengan penjelasan yang disampaikan Partisipan 2 sebagaimana yang tergambar dalam hasil wawancara berikut.

"Ya, Bapak mudir memang dalam kegiatan upacara selalu menyisipkan pesan agar para guru yang ada pada pondok pesantren As'ad ini selalu bekerja dengan penuh keihklasan. Mudir berkeyakinan bahwa ketika kami bekerja dengan ikhlas maka Allah akan tidak menyia-nyaikan perjuangan kami. Dan kami memang merasa tersentuh dengan pesan-pesan yang disampaikan oleh mudir tersebut, karena cara penyampaiannya yang menyejukkan ketika kami mendengarkannya". 
c. Meningkatkan fasilitas kerja.

Berdasarkan keterangan yang disampaikan oleh mudir pondok pesantren As'ad, diketahui bahwa cara lain yang dilakukannya dalam rangka meningkatkan motivasi para guru adalah dengan berupaya meningkatkan fasilitas kerja. Hal itu dapat diperhatikan dalam hasil wawancara berikut ini.

"Salah satu cara yang saya lakukan untuk meningkatkan motivasi para guru adalah dengan berupaya meningkatkan fasilitas kerja. Yaitu secara bertahap melengkapi fasilitas-fasilitas penting yang dibutuhkan oleh para guru, seperti melakukan penambahan unit komputer yang bisa membantu guru menyelesaikan berbagai tugas. Membangun ruang kerja guru yang lebih luas, yang mana sebelumnya masih sempit, tapi sekarang sudah lebih lapang, dan dipercantik dengan cat dan interior baru. Memperbaharui meja dan kursi para guru yang dianggap telah termakan usia dan terlihat using. Semuanya ini dilakukan dalam rangka memberikan rasa nyaman kepada guru dalam bekerja, dan dengan demikian diharapkanpara guru semakin termotivasi dalam menjalankan tugas dan kewajibannya"

Ketika penulis melakukan observasi ke lokasi pondok pesantren tersebut, memang terlihat bahwa ada peningkatan dalam penambahan fasilitas kerja guru maupun fasilitas lainnya. Ruangan kerja guru dan gedung-gedung belajar terlihat baru selesai direnovasi, interior dan eksteriornya terlihat relatif serba baru.

\section{d. Menjaga kedekatan dengan para guru \\ Cara lain yang dilakukan mudir dalam} rangka meningkatkan motivasi para guru adalah dengan menjaga kedekatan para guru. Hal itu dapat dipahami dari penjelasan yang disampaikan oleh mudir dalam hasil wawancara sebagai berikut:

"Selanjutnya, cara lain yang saya lakukan dalam rangka meningkatkan motivasi para guru adalah dengan menjaga kedekatan para guru. Maksudnya adalah bahwa saya tidak mau menjaga jarak dengan para guru, karena saya menganggap bahwa guru merupakan ujung tombak dari kesuksesan pondok pesantren ini sampai sekarang, guru adalah mitra saya dan saudara saya dalam membimbing dan melayani para santri. Pondok pesantren ini tidak akan maju jika tidak didukung oleh ketekunan dan keikhlasan perjuangan para guru."

Penjelasan mudir tersebut sesuai pula dengan keterangan yang disampikan oleh Partisipan 3 dalam hasil wawancara berikut:

"Bapak mudir memang sosok yang dekat para guru, beliau selalu ramah dengan semua guru dalam semua kesempatan, sesekali beliau mau duduk bersama para guru dan berbagi cerita di ruang kerja guru, beliau juga cepat tanggap jika ada diantara para guru yang menghadapi masalah atau tertimpa musibah, beliau juga selalu memenuhi undangan para guru jika guru yang bersangkutan melaksanakan hajatan."

Di sisi lain, hasil penelitian juga menhugkapkan berbagai kendala kepemimpinan mudir dalam meningkatkan motivasi guru pada pondok pesantren As'ad kota Jambi, dan cara mengatasinya. Berdasarkan hasil obervasi dan wawancara yang penulis lakukan kepada partisipan penelitian, dapat dikemukakan bahwa kendala kepemimpinan mudir dalam meningkatkan motivasi guru pada pondok pesantren As'ad kota Jambi dan cara mengatasinya. sebagai berikut:

\section{a. Kekurangan Dana}

Salah satu bentuk kendala kepemimpinan mudir dalam meningkatkan motivasi guru pada pondok pesantren As'ad kota Jambi, hal itu berdasarkan hasil wawancara penulis dengan mudir sebagai berikut:

"Salah satu kendala yang saya rasakan dalam meningkatkan motivasi guru pada pondok pesantren As'ad ini adalah minimnya alokasi dana yang bisa digunakan untuk memberikan bonus kepada para guru. Dana yang kita miliki hanya berfokus pada pengeluaran rutin pondok pesantren, dan itupun pas-pasan. Jadi kalau yayasan memiliki dana melimpah maka untuk meningkatkan motivasi kita bisa memberikan penghargaan kepada guru yang berprestasi dan 
rajin dalam bentuk uang, atau kepada semua guru diberikan bonus gaji ketiga belas seperti PNS, atau setiap akhir tahun mengajak para guru study tour ke luar provinsi. Maka cara mengatasi keterbatasan dana tersebut adalah dengan memberikan pemahaman kepada para guru agar sama-sama memaklumi akan keadaan keterbatasan keuangan yang dimiliki oleh pondok pesantren As'ad ini, dan berupaya memenuhi kebutuhan-kebutuhan pokok yang terjangkau oleh keuangan yang ada."

Penjelasan mudir di atas sesuai pula dengan penjelasan yang disampaikan oleh bendahara yayasan pondok pesantren As'ad, yang mana menurutnya keuangan pondok pesantren As'ad hanya cukup untuk pembiayaan operasional rutin. Hal ini tercermin dalam hasil wawancara sebagai berikut:

"Kondisi keuangan pondok pesantren As'ad termasuk pas-pasan. Yakni hanya cukup untuk pengeluaran rutin pondok pesantren, seperti membayar gaji guru setiap bulan, membayar listrik, membayar air, uang pemeliharaan sarana dan prasarana, dan sebagian lagi digunakan untuk pembangunan fisik pondok pesantren".

\section{b. Keberagaman keinginan para guru}

Bentuk lain dari kendala kepemimpinan mudir dalam meningkatkan motivasi guru pada pondok pesantren As'ad kota Jambi ialah keberagaman keinginan para guru, hal itu berdasarkan hasil wawancara penulis dengan mudir sebagai berikut:

"Kendala lainnya yang saya rasakan dalam hal upaya meningkatkan motivasi para guru adalah keinginan para guru yang bermacam ragam, saya jadi susah mengikuti keinginan mereka, jika memenuhi semuanya saya jelas tidak mampu, kalau dipenuhi sebagian saja maka dikhawatirkan akan ada kecemburuan sosial diantara sesama guru yanga ada."

Lebih lanjut mudir menjelaskan dengan jumlah guru yang cukup banyak tentu keinginan mereka juga cukup banyak, maka di situlah letak permasalahannya yaitu susah untuk memenuhi semua keinginan guru, akhirnya pihaknya hanya memenuhi sesuatu yang terjangkau saja, dengan harapan para guru bisa menerima apa adanya, dan bisa bersabar dengan segala keterbatasan yang dimiliki oleh pondok pesantren As'ad.

\section{PEMBAHASAN}

Berdasarkan hasil penelitian tersebut dapat dipahami bahwa apa yang telah dilakukan oleh mudir pondok pesantren As'ad kota Jambi dalam rangka meningkatkan motivasi guru telah baik. Upaya itu perlu dipertahankan dan alangkah lebih baiknya jika ditingkatkan di masa-masa yang akan datang.

Ketika upaya peningkatan motivasi guru terlaksana dengan baik maka dapat memberikan efek yang lebih baik terhadap kinerja guru. Hal itu telah terbukti dari apa yang telah terjadi pada pondok pesantren As'ad kota Jambi, yang mana sampai saat ini merupakan pondok pesantren paling sukses atau paling diminati di provinsi Jambi.

Berikut penulis sampaikan bahasan mengenai hasil penelitian ini, yang mana peran pemimpin atau dalam hal ini disebut sebagai mudir dalam meningkatkan motivasi guru pada pondok pesantren As'ad kota Jambi adalah sebagai berikut.

\section{a. Memberikan reward and punishment}

Upaya meningkatkan motivasi guru dengan memberikan reward and pusibment memang cukup positif dilakukan, sebab dengan penghargaan dan sanksi diberikan menjadikan yang bersangkutan semakin semangat dalam melaksanakan sebuah pekerjaan. Hal i tu sesuai dengan pendapat menurut Sutrisno (2011) dalam teori harapan tentang motivasi mengandung beberapa hal, salah satunya menekankan imbalan. Artinya bahwa seseorang semakin semangat melakukan suatu pekerjaan karena ada harapan menerima imbalan dari pekerjaannya. Hal ini sesuai pula dengan pendapat Sutikno (2012) yang mengatakan seorang pemimpin yang ingin meningkatkan motivasi karyawannya dapat 
dilakukan dengan berbagai cara, diantaranya yaitu dengan memberikan insentif material kepada karyawan yang berprestasi baik, dan memberikan semacam punishment bagi karyawan atau bawahan yang memiliki kinerja buruk.

Simarmata (2014) juga mengatakan bahwa salah satu upaya yang dapat dilakukan oleh kepala sekolah untuk meningkatkan motivasi guru ialah dengan memberikan penghargaan kepada mereka. Penghargaan yang diberikan oleh pimpinan kepada para guru yang memiliki kinerja baik dapat berupa saja, bisa saja dalam bentuk ucapan selamat, kata-kata pujian, buku referensi yang diminati, pakaian, alat-alat pendidikan, atau bisa juga dalam bentuk uang pembinaan. Sementara itu sanksi bisa saja dalam bentuk teguran secara lisan, teguran secara tertulis, pemotongan gaji, penundaan kenaikan pangkat, dan bahkan sampai pada pemutusan hubungan kerja atau pemecatan. Maduratna (2013:83) menjelaskana bahwa kepala memberikan motivasi kepada para guru dalam bentuk memberikan hadiah dan menyampaikan katakata pujian.

\section{b. Mengajak guru untuk bekerja secara ikhlas.}

Keikhlasan atau ketulusan merupakan modal kuat bagi seseorang untuk mencapai kesuksesan dalam sebuah perkerjaan. Sebab ketika seseorang melaksanakan sebuah pekerjaan dengan penuh ketulusan maka ia akan bekerja secara profesional dan akan mengerjakan pekerjaan tersebut dengan sungguh-sungguh dan penuh tanggung jawab. Hal itu juga dapat diperhatikan dari Ayat Al-Qur'an (Q.S.AlBayyinah ayat 4) yang mana Allah SWT memerintahkan manusia menyembah kepada Allah dengan penuh keikhlasan.

Bekerja secara ikhlas bukan berarti tidak butuh dengan gaji, akan tetapi gaji bukan menjadi ukuran satu-satunya dan bukan menjadi target utama dalam bekerja. Yang menjadi target dan tujuan adalah kepuasan bathin dan keberkahan hidup serta ridha Allah yang maha kuasa. Bekerja secara ikhlas tidak menjadikan atasan sebagai satu-satunya pengawas pekerjaannya, akan tetapi ia menjadikan dirinya dan Tuhan sebagai pengawas utama pada setiap kegiatan yang dilakukannya, sehingga ia selalu semangat dan selalu hati-hati dalam bekerja dan tidak berani untuk melanggar berbagai aturan yang telah ditetapkan.

Bekerja secara ikhlas memiliki spirit tersendiri, spirit yang hanya tertuju kepada Allah swt, yakni bekerja tanpa dibebani oleh sesuatu yang terkadang bisa menjadi penghambat di dalam bekerja. Gaji, upah, dan segala bentuk hak lainnya adalah hal yang tetap diterima secara profesional, akan tetapi semuanya itu tidak dijadikan sebagai tujuan utama. Dengan demikian, orang yang bekerja secara ikhlas memeiliki motivasi yang selalu stabil, yakni mengerjakan segala tugas, tanggung jawab, dan kewajibannya sesuai dengan prosedur yang telah diterimanya.

\section{c. Meningkatkan fasilitas kerja.}

Fasilitas kerja merupakan hal penting yang harus diperhatikan dalam sebuah pekerjaan. Hal ini sejalan dengan pendapat Simarmata (2014) yang mengatakan bahwa salah satu upaya yang dapat dilakukan oleh kepala sekolah untuk meningkatkan motivasi guru ialah dengan memberikan ruang kerja yang nyaman. Selain dari ruang kerja yang nyaman fasilitas kerja dapat juga berupa ketersediaan unit komputer yang dapat digunakan oleh setiap guru, jaringan internet yang memiliki koneksi cepat, buku referensi yang mencukupi kebutuhan, dan perlengkapan pengajaran yang tercukupi.

\section{d. Menjaga kedekatan dengan para guru}

Kedekatan pimpinan dengan bawahan merupakan komponen pokok untuk meningkatkan motivasi kerja seorang bawahan, termasuk juga dengan kedekatan pimpinan yayasan sebuah sekolah atau mudir dengan para guru. Hal ini sesuai dengan hasil penelitian Alfianis (2014) juga berpendapat bahwa untuk meningkatkan motivasi kerja guru maka seorang kepala atau pimpinan harus menjalin hubungan yang harmonis dengan para guru tersebut.

$$
\text { Penelitian Rusydi (2012) juga }
$$

membuktikan bahwa diantara strategi pimpinan 
sekolah dalam meningkatkan motivasi kerja guru adalah dengan menciptakan hubungan yang harmonis dalam lingkungan sekolah termasuk dengan para guru. Kedekatan pimpinan dengan guru merupakan hal yang penting, kedekatan atau keharmonisan memberikan energi positif kepada kedua belah pihak untuk saling melengkapi dan mencapai kesuksesan bersama.

Wardani, dkk (2013) juga membuktikan bahwa salah satu upaya yang dilakukan oleg kepala sekolah SMA N 2 Semarang untuk memotivasi para guru adalah dengan melakukan pendekatan secara psikis terhadap para guru. Begitu juga dengan Yoqid (2016) yang menyebutkan bahwa pendekatan dalam bentuk menjaga komunikasi interpersonal yang baik memiliki peran dalam membangun motivasi kerja guru.

Selanjutnya penulis sajikan pembahasan mengenai kendala pimpinan dalam meningkatkan motivasi kerja guru pada pondok pesantren As'ad kota Jambi, yaitu ada dua: 1) Keterbatasan dana 2) Keberagaman keinginan para guru. Hal sesungguhnya merupakan kendala umum yang dihadapi oleh para pimpinan lembaga pendidikan. Menurut Karwati (2013) di sisi lain seorang pimpinan sekolah mendapat hambatan dari 3 hal yaitu: 1) Kondisi Pribadi Kepala Sekolah, 2) Organisasi Sekolah, 3) Lingkungan Eksternal.

\section{KESIMPULAN}

Berdasarkan uraian yang telah penulis sampaikan, dapatlah diambil kesimpulan bahwa peran pemimpin dalam meningkatkan motivasi kerja guru pada pondok pesantren As'ad kota Jambi yaitu dengan cara memberikan reward and punishment, mengajak guru untuk bekerja secara ikhlas, meningkatkan fasilitas kerja, serta menjaga kedekatan dengan para guru. Sedangkan kendala pimpinan dalam meningkatkan motivasi kerja guru pada pondok pesantren As'ad kota Jambi meliputi keterbatasan dana dan keberagaman keinginan para guru.
Berdasarkan hasil penelitian ini maka penulis menyarankan kepada pihak pimpinan atau mudir pondok pesantren As'ad kota Jambi agar melakukan variasi dalam hal meningkatkan motivasi kerjapara guru, sehingga ke depannya semakin memberikan efek yang lebih baik.

\section{DAFTAR PUSTAKA}

Achua, C. F., \& Luissier, Robert N. (2010). Effective Leadership. Ed.4. Canada: Cengage.

Alfianis. (2014). Upaya kepala sekolah dalam meningkatkan motivasi guru dalam mengajar di sekolah. Jurnal Babana Manajemen Pendidikan, 2(1).

Thoonen, Erik. (2011). How to improve teaching practices: The role of teacher motivation, organizational factors, and leadership practices. SAGE Journal, 47(3).

Ivancevich, J. M., \& Robert, K. (2013). Human Resource Management, $20^{\text {th }}$ eds. USA: Mc Graw Hill.

Karwati, Euis dan Donni Juni Priansa. 2013. Kinerja dan Profesionalisme Kepala Sekolah. Alfabeta. Bandung.

Maduratna, Munika. (2013). Peranan Kepemimpinan Kepala Sekolah Dalam Meningkatkan Efektivitas Kerja Guru Dan Pegawai Di Sekolah Dasar Negeri 015 Samarinda. E-Journal Administrasi Negara, 2013, 1 (1): 70-84 ISSN 00000000, ejournal.an.fisip-unmul.org

Manullang, M. (2007). Manajemen Sumber Daya Manusia. Yogyakarta: BPFE.

Moleong, L. J. (2010). Metodologi penelitian kualitatif. Bandung: Remaja Rosda Karya.

Mulyasa, E. (2004). Manajemen Berbasis Sekolab: Konsep, Strategi dan Implementasi. Bandung: Remaja Rosdakarya.

Rusydi. (2014). Strategi kepala sekolah dalam meningkatkan motivasi kerja guru pada MIN Beureunuen Kabupaten Pidie.Tesis. Program Pascasarjana Universitas Syiah Kuala. Banda Aceh: 
https://etd.unsyiah.ac.id/index.php?p=s how_detail\&id=3949

Siagian, S. P. (2009). Kiat meningkatkan produktivitas kerja. cetakan ke-2. Jakarta: Rineka Cipta.

Simarmata, R. H. (2014). Upaya peningkatan motivasi kerja guru sekolah dasar. Jurnal Bahana Manajemen Pendidikan, 2(1).

Suhendar, dkk. (2017). Analisis pengaruh kepemimpinan kyai, budaya pesantren, dan motivasi kerja guru terhadap mutu pendidikan pesantren di Provinsi Banten. Jurnal Penelitian Pendidikan UNNES, 34(2).

Setyati, S. (2012). Pengaruh kepemimpinan kepala sekolah, motivasi kerja, dan budaya sekolah terhadap kinerja guru. Jurnal Pendidikan dan Teknologi Kejuruan, 22(2).

Sutikno, S. (2012). Manajemen pendidikan. Lombok: Holistica.

Sutrisno, E. (2011). Manajemen Sumber Daya Manusia. Jakarta: Kencana.

Usman, H., dkk. (2009). Metodologi penelitian sosial. Jakarta: Bumi Aksara.

Usman, H., dkk. (2016). Pengaruh Kepemimpinan dalam Meningkatkan Personil Kinerja di Islam Tradisional Sekolah Papan. Jurnal Ilmiah Peuradeun, $4(2)$.

Wahjosumidjo.(2010). Kepemimpinan Kepala Sekolab: Tinjauan Teoritik Dan Permasalahannya. Jakarta: Raja Grafindo Persada.

Wardani, Ayu, dkk. (2013). Peran Kepemimpinan Kepala Sekolah Perempuan Terhadap Motivasi Kerja Guru (Studi di SMA N 12 Semarang). Unnes Civic Education Journal 2 (2): 8-15. ISSN: 2252-6293: http://journal.unnes.ac.id/sju/index.ph $\mathrm{p} /$ ucej

Yoqid, Muhammad. (2016). Peran Komunikasi Interpersonal Kepala Sekolah Terhadap Motivasi Kerja Guru di Sekolah Menengah Atas Islam Samarinda. EJournal Ilmu Komunikasi, 4 (2) 2016 : 24 -
35 ISSN 0000-0000, ejournal.ilkom.fisipunmul.ac.id 